\title{
Amicable Dispute Resolution in Civil and Commercial Matters in Ethiopia: Negotiation, Conciliation and Compromise
}

\author{
Tecle Hagos Bahta *
}

'Discourage litigation. Persuade your neighbours to compromise whenever you can. Point out to them how the nominal winner is often a real loser in fees, expenses and waste of time'. (Abraham Lincoln)

\section{Abstract}

Amicable dispute settlement methods play a major role in the resolution of civil and commercial disputes. These mechanisms present advantages to the parties as compared to arbitration and litigation. The Civil Code of 1960 contains provisions on Conciliation and Compromise, which set out the minimum legal framework for practical use by disputing parties in civil and commercial matters. Conciliation and compromise are in the main regulated under Arts. 3318-3324 and 3307-3317 respectively. The Civil Procedure Code of 1965 also consists of several provisions on compromise (Arts. 274-277). Generally, disputes are legally and conveniently amenable and better resolved through these amicable dispute settlement methods. However, whether they are put in use entirely depends on the free will of the disputing parties'. They can only be resorted to whenever the disputing parties commit themselves to use them in their contractual agreements. For certain other disputes, these amicable dispute settlement mechanisms are compulsory; in such cases, policy rationale dictates that disputes of such nature should be swiftly resolved through amicable dispute settlement methods. Some other disputes are, however, vested exclusively in the courts. This article distinguishes arbitration from conciliation. It is discussed whether conciliation differs from mediation. Attempt has also been made to shed light on the nature and application of concilioarbitration in Ethiopia. The legal framework underpinning negotiation, conciliation, and compromise is expounded. Furthermore, the legal lacunae in relation to conciliation is addressed.

\section{Key terms}

Mediation · Conciliation · Compromise $\cdot$ Concilio-arbitration

DOI http://dx.doi.org/10.4314/mlr.v13i1.1

This article is licensed under a Creative Commons Attribution-NonCommercial-

NoDerivs (CC BY-NC-ND)

\footnotetext{
* Tecle Hagos Bahta Associate Professor of law, Mekelle University; currently, Senior Lecturer of Law, Department of Law, University of Botswana. The Author can be reached for comments at: teclino2u@gmail.com
} 


\section{Introduction}

Alternative dispute settlement mechanisms play a significant role in the resolution of civil and commercial disputes in Ethiopia. Direct negotiation and conciliation do have no less importance than arbitration. While arbitration has (of late) attracted the attention of legal scholars and practitioners, the paucity of literature in relation to the amicable dispute resolution mechanisms shows that little, if any, attention has been devoted. That notwithstanding, there is a steady increase in the number of decided cases in connection with such amicable dispute settlement mechanisms by the Cassation Division of the Federal Supreme Court. In order for courts to ground their judgments on sound theoretical and conceptual underpinnings, therefore, there is the need for concerted efforts to enhance the conceptual and legal expositions in this area.

The first section of this article clarifies the basic conceptual and legal foundations of negotiation, mediation or conciliation in Ethiopia, and it sets out the conceptual and legal grounds for distinguishing arbitration from conciliation or mediation. In Section 2, the nature and conceptual underpinnings of amicable dispute settlement mechanisms and their distinguishing features are highlighted. Furthermore, the role of the legislature, courts and practicing lawyers (advocates) in properly and carefully paying attention to the overall trade-offs between settlement of disputes and litigation is discussed. The legal framework for conciliation, as it stands today, and the legal lacunae thereof are enunciated in Section 3. Finally, the salient peculiarities, enforcement and the legal framework on compromise (that is to say, the outcome of direct negotiation, mediation or conciliation) are discussed in Section 4 based on the relevant legal provisions and authoritative cases.

\section{Arbitration and Amicable Dispute Settlement Mechanisms}

Arbitration exhibits differing attributes from the other non-adversarial dispute settlement methods; it is actually more akin to litigation than the amicable dispute resolution mechanisms. Arbitration is not thus the subject of this article. However, a brief discussion is ventured below to highlight the salient dissimilarities between arbitration and the amicable dispute settlement mechanisms in general and conciliation or mediation in particular. In Mukemil Mohammed v Miftah Kedir, ${ }^{1}$ the Cassation Division of the Federal Supreme Court identified four alternative dispute resolution mechanisms, viz., negotiation, conciliation, mediation, and arbitration. The Court, then, proceeded to determine whether the dispute settlement method that the disputing parties employed to resolve their disputes was conciliation or arbitration.

\footnotetext{
${ }^{1}$ Cassation Case No. 38794 [2001EC] Fed. Sup. Ct. Rep., Vol. 9, p.182.
} 
It should be noted that 'unlike an arbitrator, a conciliator is not empowered to make a binding decision and this fact forms the main distinction between arbitration and conciliation'. ${ }^{2}$ Notwithstanding the aforesaid statement, the boundary line between arbitration and conciliation is not clearly delineated. According to René David, ${ }^{3}$ '[i]t is difficult to draw a clear distinction between arbitration and conciliation. Confusion may arise here from the fact that arbitrators often receive powers to decide according to equity or may be directed to apply law rules or legal principles other than the rules or principles which a judge would have to apply'. ${ }^{4}$ He further noted that 'arbitrators may be, in many cases, inclined to work out a decision which will be acceptable to all parties concerned'. 5

That notwithstanding, René David noted that 'there exists a fundamental difference between arbitration and conciliation. The solution proposed by the conciliator or mediator must be accepted by the [disputing parties] concerned, and it becomes binding only when they have adhered to it; the decision of the arbitrator, on the contrary, is binding on interested parties independently of any acceptance... ${ }^{6}$

In Mukemil Mohammed $v$ Miftah Kedir, the Court decided that the dispute settlement process that the parties employed was arbitration. In distinguishing arbitration from conciliation, the Court took cognizance of three facts that the Court found relevant for its decision: ${ }^{7}$ firstly, the parties had entrusted the 'arbitrators' with the decision-making power to which the parties vouched to accept as binding; secondly, pursuant to the arbitration clause that the parties entered into, the parties had agreed that the process would be governed under Arts. 3325-3346 of the Civil Code; and, finally, that arbitration proceedings would not be amenable to the strict application of civil procedure rules. The Court, thus, decided to recognize the process as arbitration. However, all the 'arbitrators/ conciliator' ${ }^{8}$ had given their testimony that they all had believed to have been appointed to conciliate between the parties and accordingly acted as conciliators and not as arbitrators.

\footnotetext{
${ }^{2}$ Nael G. Bunni (2005), FIDIC Forms of Contract, $3^{\text {rd }}$ ed., Blackwell Publishing, p.445.

${ }^{3}$ René David (1985), Arbitration in International Trade, Kluwer Law International, p.7.

${ }^{4}$ Ibid.

${ }^{5}$ Ibid.

${ }^{6}$ Ibid.

${ }^{7}$ Mukemil Mohammed v MiftahKedir, supra note 1, at 175.

${ }^{8}$ In this case, the Cassation Division reversed the decisions of the Federal First Instance Court and High Court; both had decided that the dispute settlement process employed by the parties was conciliation and not arbitration.
} 
In what appeared to be an identical case, the High Court of Botswana, in St. Joseph's College v Dawson \& Fraser (Pty) Ltd and Others, ${ }^{9}$ noted that, in order to '.. ascertain the true legal nature of what had in reality occurred between the parties, one had to look deeper into the details of the agreement, the characteristics of the process and its expected outcome'. The Court, then, concluded that ' $[t]$ he determining factor in the matter was that the parties agreed to be bound by the process. It became an irrevocable outcome situation in so far as neither disputant could revoke the opinion. The process was therefore clearly not mediation' ${ }^{10}$ It should be noted, however, that parties' agreement to have a 'final and binding decision' handed down by a third-party neutral may exclude the mediation or conciliation process; that does not, however, necessarily make it an arbitration.

The distinguishing feature for arbitration is cogently presented by Duncan Wallace as follows: ${ }^{11}$

If $[\ldots]$ a person is appointed with the intention that he should hear the parties and their evidence and decide in a judicial manner, then, he is an arbitrator, though a mere absence of a hearing, provided it does not result in any unfairness to the parties, will not necessarily invalidate an award ... the intention in such cases is that there should be a judicial inquiry worked out in a judicial manner.[Emphasis supplied].

In Mukemil Mohammed $v$ Miftah Kedir, the respondent argued that the process should not be deemed to be arbitration as it was too informal. In countering this argument, the Cassation Division stated that the arbitrators are not bound to comply with the stringent procedural requirements as courts do.

${ }_{9}^{9}$ [2005] 2 BLR 418 (HC) (Per Justice Marumo).

${ }^{10}$ Ibid.

${ }^{11}$ I.N. Duncan Wallace (1970), Hudson's Building and Engineering Contracts, $10^{\text {th }}$ ed., Sweet and Maxwell, p.826 (In distinguishing arbitration from other decisional or judgmental processes (such as expert determination, valuers, assessors, adjudicators, etc, it is stated herein thus:

If a person is appointed, owing to his skill and knowledge of the particular subject, to decide any questions, whether of fact or of value, by the use of his skill and knowledge and without taking any evidence or hearing the parties, he is not, prima facie, an arbitrator ... if a man is, on account of his skill in such matters, appointed to make valuations, in such manner that in making it he may, in accordance with the appointment, decide solely by the use of his eyes, his knowledge, and his skill, he is not acting judicially: he is using the skill of a valuer, not of a judge ... they have to determine the matter by using solely their own eyes, knowledge and skill.)

In this regard, see, for instance, the role of the so-called arbitrator under Art.2271 of the Civil Code (wherein it is stated thus: "(1) The price may be referred to the arbitration of a third party. (2) There shall be no sale where such third party refuses or is unable to make an estimate." 
However, arbitration like any judicial or quasi-judicial function, presupposes the maintenance of the minimum procedural and substantive requirements in the process of disposition of justice.

Conciliation is, thus, less formal than arbitration as it is aimed to 'avoid the risk of losing costly binding dispute processes and assists the parties in developing creative solutions'. ${ }^{12}$ Furthermore, it is a 'process that can preserve commercial relationships and, in some cases, even resurrect relationships'. ${ }^{13}$ As Jones noted: ${ }^{14}$

The non-binding processes allow parties to share the risk of losing, and to devise outcomes different to those produced by a binding process. The result will inevitably be a compromise, but the important point is that, because the process is voluntary and non-binding, neither party will lose. The result is a commercially workable solution, although it may not be a 'win-win' solution. Usually neither party will be pleased with the outcome as they would be if they had 'won'.

In contradistinction to arbitration and litigation, therefore, the amicable dispute settlement mechanisms (i.e., direct negotiation, conciliation or mediation) ensure parties' control and satisfaction over the outcome.

\section{Amicable Dispute Settlement Mechanisms: Choosing the Appropriate Method}

\subsection{Direct negotiation}

Nael Bunni stated that 'direct negotiation between parties in dispute without the intervention of a third party is perhaps the most readily available method of dispute resolution and the most effective'. ${ }^{15}$ Indeed, it is the most informal, flexible and least regulated by law. Not only must this be the most predominant but also the most cost-effective, amicable, efficient and all-inclusive dispute settlement method. Negotiation, as Asouzu stated, is: “...a process leading to joint decision-making by the disputing parties themselves. It is an interactive

\footnotetext{
${ }^{12}$ Doug Jones (2005), 'Various Non-binding (ADR) Processes', in New Horizons in International Commercial Arbitration and Beyond, in (ed.), Albert Jan van den Berg, ICCA, Kluwer Law International, p.371.

${ }^{13}$ Id., at 370.

${ }^{14}$ Id., at 367 .

${ }^{15}$ Bunni (2005), supra note 2, p. 441.
} 
process of information exchange and learning, leading ultimately to a decision accepted to both disputing parties". ${ }^{16}$

Negotiation is characterized by the absence of a third party neutral in facilitating the interactive communications between the parties. Negotiation is, thus, a process 'leading to joint decision-making by the disputing parties themselves' ${ }^{17}$ Most commercial disputes are usually resolved at their early stages through such bilateral interactions, discussion, and mutual concessions between the disputing parties.

It is, thus, common for legislatures and contracting parties to firmly place negotiation as the first option for the settlement of disputes. It has, for instance, mustered up salience in the government procurement contracts to the extent that 'direct negotiation' between a contractor/supplier/service-provider, on the one hand, and the procuring entity, on the other, has become the only recourse for the settlement of disputes prior to resort to courts. ${ }^{18}$ Furthermore, Art. 76(1) of the Mining Proclamation No. 678/2010 ${ }^{19}$ provides that '[a]ny dispute, controversy or claim between the Licensing Authority and a licensee [mining concession company] arising out of or relating to an agreement for reconnaissance, exploration, retention, or mining or the interpretation, breach or termination thereof shall, to the extent possible, be resolved through negotiation.' Similarly, Art. 25(1) of the Petroleum Operations Proclamation No. $295 / 1986^{20}$ provides for the application of negotiation to resolve disputes prior to arbitration.

\subsection{Conciliation and mediation}

In mediation or conciliation, the process of resolving disputes is facilitated by a third party neutral. As will be discussed below, the role of the third party neutral is quintessential in bringing the parties together to discuss their disputes and arrange for settlement between them.

Whether conciliation and mediation are different methods of dispute settlement has, however, been an issue of contention. It is stressed, for instance, by Jones ${ }^{21}$ that, whilst they are conceptually similar, 'the two processes are,

${ }^{16}$ Amazu A. Asouzu (2001), International Commercial Arbitration and African States: Practices, Participation and Institutional Development: Cambridge University Press, p. 18.

${ }^{17}$ Id., at 18 .

${ }^{18}$ See Art.26 General Conditions of Contract (GCC) of the Standard Bidding Documents (SBD) for supplies, construction and services issued by the Federal Public Procurement and Property Administration Agency (FPPPAA) in 2011, available at : http://www.ppa.gov.et.> (Last visited on 16August 2019).

${ }^{19}$ Fed. Neg. Gaz. Year 16, No.45, 2010.

${ }^{20}$ Neg. Gaz., Year 45, No.6, 1986.

${ }^{21}$ Jones, supra note 12, p. 368. 
distinguished by the degree of involvement of the neutral third party'. ${ }^{22} \mathrm{He}$ argues that:

A mediator not only chairs the meetings of the parties, as does a conciliator, but also takes an active role in the discussions and negotiations. As such, a mediator has a greater involvement in the substantive issues of the dispute than does a conciliator, sometimes even producing a report.

Others hold a differing view. Nael Bunni, ${ }^{23}$ for instance, is of the view that the mediator is the passive intervener and the conciliator is the active one. He states that conciliation is where:

... the neutral party takes a more active role probing the strengths and weaknesses of the parties' case, making suggestions, giving advice, finding persuasive arguments for and against each of the parties' positions, and creating new ideas which might induce them to settle their dispute... [if] the parties fail to reach agreement, the neutral party himself is then required to draw up and propose a solution which represents what, in his view, is a fair and reasonable compromise of the dispute.

According to Nael Bunni, mediation is where the mediator '... simply performs the task of persuading the parties in dispute to change their respective positions in the hope of reaching a point where those positions coincide, a form of shuttle diplomacy without actively initiating any ideas as to how the dispute might be settled'. ${ }^{24}$ Nevertheless, he admits that there is no universal agreement in such characterization.

Asouzu also admits ${ }^{25}$ that it is common to treat the two methods as different. However, there is a significant confusion amongst writers as to what exactly distinguishes mediation from conciliation. ${ }^{26}$ As alluded to above, Nael Bunni ${ }^{27}$ argues, for instance, that conciliation is a more formal process than mediation. He further states that conciliation has an added advantage because '... should no amicable solution be reached, the conciliator has a duty to attempt to persuade the differing parties to accept his own solution to the dispute'. ${ }^{28}$

${ }^{22}$ Ibid.

${ }^{23}$ Bunni, supra note 2, pp. 426-8.

${ }^{24}$ Id., p.425-6.

${ }^{25}$ Asouzu, supra note 16, p.19.

${ }^{26} \mathrm{Ibid}$, at 19 (stating that the description of the functions of a mediator by one writer is taken for by another to be that of the conciliator and vice versa).

${ }^{27}$ Nael G. Bunni (1997), The FIDIC Form of Contract: The Fourth Edition of the Red Book, $2^{\text {nd }}$ ed., Blackwell Science Ltd., p.428.

${ }^{28}$ Ibid; See also Margaret Moses (2008), The Principles and Practice of International Commercial Arbitration, CUP, p.14 (wherein it is stated that '[a] conciliator listens to the two parties, hears their different positions, and then sets forth a proposed settlement 
Experts admit that there is no uniform international conceptualization of the two methods. Bunni epitomizes this distinction as he mentions that the functions attributed to mediation in the American Arbitration Association (AAA) is not in-keeping with the process of conciliation in the Continental Europe. ${ }^{29}$

It is true that negotiation, conciliation or mediation are outside court dispute settlement methods in which an amicable settlement of dispute is sought through mutual concessions. Such mutual concessions are made to achieve a settlement acceptable to both parties in which there is no winner or loser. This process of 'giving and taking' ensures that parties are involved in jointly solving the problem for mutual gain rather than winning their positions. These processes are much opted, inter alia, for the 'win/win' situation rather than the 'winner-takesit-all' outcome in arbitration and litigation. Unlike direct negotiation, both mediation and conciliation are characterized by the involvement of a neutral third party-mediator/conciliator- who helps in facilitating the negotiation process between the disputing parties.

Asouzu, concurring with Jones, recognizes that the mediator is the active third party intervener. He states that conciliation is “... a less formal procedure than mediation or one in which the neutral third party is less active... will not generally make a recommendation as to the terms but a mediator will go further and formulate his or her own recommendation on settlement terms". ${ }^{30}$

Asouzu is, however, of the opinion that the distinction is pedantic; the passive or active nature of the conciliator or mediator simply is left to the discretion of the said neutral party and depends on whether or not the solution is forthcoming easily from the parties. Asouzu concludes that 'the making of recommendations, which is said to be a feature of active participation by the mediator, is not unique to mediation' ${ }^{31}$ He rather commented that 'whether or not a third party intervener will make a recommendation depends on the circumstances and is a question of degree and form'. He further observed that the third party intervener would 'skillfully' make recommendations only if the likelihood of acceptance is great'. ${ }^{32}$

It should also be noted that, in many legal systems, the terms 'mediation' and 'conciliation' are rather used interchangeably. In other countries, they are used

agreement, representing what she believes to be a fair compromise of the dispute. If the proposal does not resolve the dispute, the conciliator may offer another proposal'. She is of the opinion that mediators can only make a specific proposal at the parties' request).

${ }^{29}$ Ibid.

${ }^{30}$ Asouzu, supra note 16, pp. 19-20.

${ }^{31}$ Ibid.

${ }^{32}$ Ibid. 
in such a way that only one of the words is used to include the meaning of the other word ('mediation' includes 'conciliation' in particular). ${ }^{33}$

In Ethiopia, the distinction is not yet clear. This obscurity is compounded by the paucity of literature in this respect. What is clear is that legislative enactments have remained loyal to the use of the term 'conciliation'. ${ }^{34}$ In this regard, one can safely conclude that it is legally allowable for the conciliator or mediator to propose terms of settlement agreement whenever it is necessary and as the surrounding circumstances warrant doing so. ${ }^{35}$ At any rate, from the reading of the laws, one cannot extrapolate the conclusion that the conciliator is legally inhibited from making recommendations or propose settlement agreements. ${ }^{36}$ As Blackaby and Partasides noted: ${ }^{37}$

The terms 'mediation' and 'conciliation' are often used as if they are interchangeable; and there is no general agreement as to how to define them. Historically, conciliator was seen as someone who went a step further than the mediator, so to speak, in that the conciliator would draw up and propose the terms of an agreement that he or she considered represented a fair settlement. In practice, the two terms seem to have merged.

In carrying out such an active role, however, it is quite important to realize that the conciliator should be cautious lest he/she should be cajoled into assuming the position of a decision-maker. It is not uncommon for the parties to hasten themselves to, advertently or inadvertently, confer that power upon the conciliator during the negotiation process. ${ }^{38}$

${ }^{33}$ See also Kazuo Takayanagi (2005), Japan in (ed.), Robert Knutson, FIDIC: An Analysis of International Construction Contracts, Kluwer Law International, p. 220.

${ }^{34}$ It is seldom, if at all, that the term 'mediation' is used in legislative enactments in Ethiopia. It is, thus, yet to be seen how the concepts will evolve in the future. In fact, recently a draft conciliation law under the auspices of the (now defunct) Ethiopian Arbitration and Conciliation Center (EACC) had been captioned 'Draft Mediation Law'.

${ }^{35}$ Art. 3320 of the Civil Code; see also the definition of 'conciliation' in Art. 136(1) of the Labour Proclamation No. 377/2003, Fed. Neg. Gaz., Year 10, No. 12, 2004 (wherein it is defined thus: “... the activity [conducted] by a private person or persons appointed by the Ministry at the joint request of the parties for the purpose of bringing the parties together and seeking to arrange between them voluntary settlement of a labour dispute which their own efforts alone do not produce."); see also Art.3320 (1) of the Civil Code (wherein it is stated thus: 'Before expressing his findings, the conciliator shall give the parties an opportunity of fully stating their views.' [Italics supplied].

${ }^{36}$ In this article, therefore, unless otherwise indicated, the terms 'mediation' and 'conciliation' are used interchangeably.

${ }^{37}$ Nigel Blackaby et al (2009), Redfern and Hunter on International Arbitration, $5^{\text {th }}$ ed., OUP, p.46.

${ }^{38}$ It is in fact the present author's experience that parties more often than not would, for instance, intimate to the conciliator that they have agreed on the salient points and what 


\subsubsection{Understanding the role of conciliation in the amicable dispute settlement system}

In Ethiopia, the traditional or customary rules of dispute settlement have been playing an important role in the settlement of all sorts of disputes relating to civil and commercial transactions. ${ }^{39}$ The Civil Code of $1960^{40}$ also catered for the basic legal framework according to which these ADR methods and Arbitration were meant to operate. Thus, direct negotiation, conciliation, ${ }^{41}$ concilio-arbitration, ${ }^{42}$ and Arbitration ${ }^{43}$ have been legally recognized in Ethiopia. ${ }^{44}$ In Mukemil Mohammed $\mathrm{v}$ Miftah Kedir, the Cassation Division of the Federal Supreme Court, as stated earlier in Section 1, recognized that there are generally four alternative dispute resolution mechanisms (viz. negotiation, conciliation, mediation, and arbitration) ${ }^{45}$ Due regard has also been given to the enforcement of the outcomes of amicable dispute resolution methods (i.e., negotiation and conciliation) by incorporating set of provisions on compromise (compromise agreement or negotiated settlement). ${ }^{46}$

It is believed that these Civil Codal provisions have given alternative dispute resolution mechanisms and arbitration the necessary legal framework. In other

are left are minor points upon which the conciliator can freely decide or that either or both are ready to accept whatever the conciliator decides as appropriate and other equivalent expressions to which the conciliator should not succumb.

39 TilahunTeshome (2007), 'The Legal Regime Governing Arbitration in Ethiopia: A Synopsis', Ethiopian Bar Review, Vol.1, No.2, p.117-118 (where it is stated that shimglina was and still is "... the dominant mode of alternative dispute resolution, particularly in the rural areas where access to law enforcement organs is very much limited.) For a critical analyses of the distinctions between the traditional 'shimglina' and the modern ADR methods and Arbitration, see Fekadu Petros, 'Underlying Distinctions Between ADR, Shimglina and Arbitration: A Critical Analysis', Mizan Law Review, Vol. 3, No.1, pp. 105-133.

${ }^{40}$ Civil Code of the Empire of Ethiopia Proclamation No.165/1960, Negarit Gazetta, Gazette Extraordinary, Year 19, No.2, May 5, 1960 (hereinafter referred to as 'Civil Code').

${ }^{41}$ Id., Arts.3318-3324.

${ }^{42}$ Id., Arts. 676 cum $731-737$ on family arbitrators.

${ }^{43}$ Id., Arts. 3325-3346.

${ }^{44}$ In the public international law sphere, Ethiopian lawyers may also be faced with the dispute resolution methods, such as: good offices, mediation, international commissions of Inquiry and state-to-state arbitration as enunciated under the Convention for the Pacific Settlement of International Disputes. See Convention for the Pacific Settlement of International Disputes (1899) Ratification Proclamation No.348/2003, Fed. Neg. Gaz, Year 9, No.69, 2003. Negotiations, conciliations and arbitrations may play significant role in resolving investors' claims, under the Ethiopian multilateral and bilateral investment treaties (BITs), in investor-state dispute settlements (ISDS) in the future.

${ }^{45}$ Mukemil Mohammed v Miftah Kedir, supra note 1, p. 174.

${ }^{46}$ Arts. 3307-3317 of Civil Code. 
words, these provisions were necessary to accord the alternative dispute resolution methods and arbitration the substantive and procedural guarantees to the parties wishing to employ them. In the absence of such provisions, ADR and arbitration might have existed in one form or another as customary dispute resolution (CDR) methods. Moreover, the Civil Code provisions provide disputing parties the minimum principles of fairness in their proceedings for granting them deference by courts once they are employed in the resolution of commercial and civil disputes.

Disputing parties find these amicable dispute settlement mechanisms more convenient vis-à-vis the adversarial mechanisms, i.e., arbitration and litigation. No doubt, the advantages thereof significantly outweigh any disadvantage that is advanced against them. Suffice it to mention here the most touted advantages that are attributed to these amicable settlement methods, namely: (i) satisfaction (win-win outcome vis-à-vis win/lose), (ii) continued relationship, or even reviving commercial relationships; (iii) easing the strict applicability of the law (instead, peaceful, harmonious and reconciliatory solution); (iv) control of outcome and procedural flexibility by the parties, (v) confidentiality, (vi) less costlier, speedier settlement of disputes, use of expertise, and (vii) ease of enforceability of outcomes.

This does not, however, mean that these methods are entirely immune from defects. Like any tool, it can be properly used or be abused. These mechanisms may, for instance, be deployed as a dilatory tactic (for buying time to plead period of prescription, for piecing up evidence together, for tantalizing a weaker disputant, etc), for harassing weaker parties (non-repeat party), etc. ${ }^{47}$

\subsubsection{The role of courts and advocates in advancing Amicable Dispute Resolution}

Courts play a significant role in the success of conciliation processes. This is done, firstly, by encouraging, or even persuading (in cases of court-referred or court-annexed ADR) disputing parties to conciliation at any stage of the proceedings. ${ }^{48}$ There is no reason for a court to burden itself with backlogs when and if such cases can be conveniently settled amicably by the parties themselves. ${ }^{49}$ Apparently, states have significant interest in not burdening their

\footnotetext{
${ }^{47}$ Karl Mackie et al. (1995), Commercial Dispute Resolution: An ADR Practice Guide, (London: Butterworths), p. 329.

${ }^{48}$ Art. 274 of the Civil Procedure Code of 1965.

${ }^{49}$ David Fosket opined thus: "No authority is needed to support the proposition that the courts welcome and encourage compromise. The reasons are manifest. In some instances, the approval of the court is necessary for a compromise to be effective. Generally speaking, however, this is necessary and the court is not concerned with the terms of the compromise. That is a matter for the parties. Since they created the dispute, they can
} 
courts with litigation that might be better conducted in another convenient forum in a just manner. Secondly, the court would compel parties to participate in ADR and Arbitration proceedings whenever the law imposes compulsory ADR and Arbitration proceedings ${ }^{50}$ for the settlement of particular disputes or whenever there is contractual ADR clause or arbitral clause agreed upon by the parties. Finally, courts would intervene in appointing a conciliator; interim measures of protection (IMP); subpoenaing witnesses; compelling evidences, enforcing compromises ('compromise settlements'), etc...

The role of advocates in the conciliation process is no less significant. At several occasions (where the present author has participated in trainings), the comment that quickly surfaced into the floor is that advocates are the primary culprits for sowing the seed of intransigence during parties' negotiations. The veracity (exactitude) or otherwise of this innuendos notwithstanding, advocates are duty-bound to comply with the professional code of conduct embodied in Regulations No.57/1999. Accordingly, the judges, at the court of law, should be on guard to see to it that any advocate remains loyal to the professional code of conduct. In this regard, at least the following two obligations must serve as a signpost: the duty to advise the client at the beginning, and the duty to advise the client at any stage of the court proceedings. In this regard, Art. 26 of the Regulation No.57/99 provides: ${ }^{51}$ "[w]hen an advocate finds that the desired result can be obtained if his client's case can be resolved by settlement rather than in court, he may encourage the consideration of the case by settlement."

The duty to advise one's client on possible outcomes and the merits and demerits of ADR, arbitration and litigation proceedings can also be extrapolated from the reading under Art. 7(1) of the Regulation which requires the advocate to give his client 'explanation based on the law as to the possible result or alternative results of the matter ...' [Emphasis supplied]. This is particularly so when one realizes that the right of the client and the duty of the advocate, as enunciated under the second limb of Art. 7(2), are complementary: that is to say, the advocate 'shall, in particular, respect the decision made by the client to solve the matter by settlement', would be rendered otiose short of such an obligation on the part of the advocates. ${ }^{52}$

dispose of it as they please." David Foskett (1980), The Law and Practice of Compromise, (London: Sweet \& Maxwell), p.113.

50 For instance, Arts. 46-52 of the Federal Cooperative Societies Proclamation No. 147/1998, Fed. Neg. Gaz. Year 5, No. 27, 1998.

51 The Federal Courts Advocates' Code of Conduct Regulations No. 57/1999, Fed. Neg. Gaz., Year 6, No.1, 1999.

${ }^{52}$ McIlwrath and Savage noted that disputing parties 'will want to make a reasonable assessment of the likely outcome of the litigation and the costs of getting alternatives along the way'. They suggest that 'conducting an early case assessment (ECA), that is to 
At any rate, it should be borne in mind that even if the precise obligation is not sufficiently defined, there is a legal basis for the courts to hold accountable an advocate who conspicuously fails to advise his clients on the possible options of ADR processes for cases which could have been conveniently and amicably resolved thereby. Secondly, the advocate is also duty-bound to '... follow up his client's case diligently and take all the necessary measures carefully and timely so as to obtain a quick and just decision'. ${ }^{53}$ The advocate should, throughout the pendency of the case, keep his eyes open for the optimal solution of the case wherein ADR proceedings should come into consideration.

Finally, as the primary objective of formulating any normative rules is predicated on maintaining the continuity of the socio-economic, political, and cultural interaction unabated, conciliation processes are envisaged to oil the wheels of the civil and commercial dispute settlement machinery. Hence, in the sphere of the international business transactions, all efforts are geared towards unhindered or uninhibited transactions. To this end, the ALI/Unidroit Draft ${ }^{54}$ Principles of Transnational Civil Procedure (2001), under Art.21, provides:

(i) The court, while respecting the parties' right to participate in litigation, should encourage settlement and reconciliation of the parties when reasonably possible. The court should facilitate the parties' participation in ADR procedure and voluntary settlement at any stage of the proceeding;

(ii) The parties, both before and after commencement of litigation, should cooperate in reasonable settlement endeavors. The Court may adjust its cost awards to reflect unreasonable failure to cooperate in this respect or bad faith participation in such settlement endeavors.

Whether these principles, as embodied in Transnational Civil Procedure Rules, have achieved the status of customary international law is still dubious. The principles have, however, been widely espoused by courts and commercial arbitral tribunals as a guidepost for allocation of costs when a disputing party fails to amicably settle its disputes in bad faith.

say, an initial evaluation of the dispute that quantifies the range of probable outcomes and the associated costs' is appropriate. For more on this, see Michael McIlwrathand John Savage (2010), International Arbitration and Mediation: A Practical Guide, (Kluwer Law International BV, The Netherlands), p. 117.

53 The Federal Courts Advocates' Code of Conduct Regulations No.57/99, supra note 51, Art. 8(2)(b).

${ }^{54}$ The full text of the Draft is on file with the author. See also https://www.unidroit.org/instruments/transnational-civil-procedure [Last visited on 16 August 2019]. 


\subsubsection{Legislative stipulations for optional or imperative use of amicable dispute settlement and Arbitration}

There have been instances wherein for some policy reasons, legislatures have opted, from time to time, for the application of amicable dispute settlement methods or arbitral proceedings in the settlement of certain specific disputes. Various legislative enactments have, thus, contained provisions on negotiation, conciliation and/or arbitration for use by parties. Such provisions are either directory ${ }^{55}$ or mandatory. In the main, the use of such dispute settlement mechanisms is optional for the parties. It is not, however, uncommon to find such stipulations envisaged for imperative application in the process of settling disputes arising out of or relative to certain specific disputes.

\section{a) Concilio-Arbitration}

This process was used under the family law in the Civil Code in Ethiopia. Indeed, the process of concilio-arbitration resembles the traditional 'shimglina' process which combines both the carrot and stick modality towards settling disputes ${ }^{56}$ Practice aside, the family arbitrators' mandate is not to serve only as arbitrators; they are entrusted with the mandate to resolve the marital disputes: first of all, amicably through conciliation, and, failing that, then through arbitration. Articles 676-677 of the Civil Code, thus, stipulated that the 'arbitrators' should attempt to reconcile the disputing spouses and, should they fail to reach a settlement agreement, they should proceed to the arbitral process. The process combines both conciliation and arbitration and, hence, the name 'concilio-arbitration'. ${ }^{57}$

Similarly, the Labor Relations Board (LRB) is empowered to assume the role of Concilio-Arbitration in the settlement of collective labor disputes in Ethiopia. In this respect, Art. 147(1)(b) and 147(2) of the Labor Proclamation No. $377 / 2003^{58}$ stipulate that the LRB (ad hoc or permanent) is enjoined 'to conciliate the parties and to give orders and decisions'. This role is also assumed by the courts in marital dispute settlement procedures under the Revised Family Code (RFC).$^{59}$ Firstly, Article $82(1)$ of the RFC provides that the Court which is

${ }^{55}$ For instance, Art. 5 of the Transfer of Technology Council of Ministers Regulations No.121/1993, Neg. Gaz. Year 52, No.53, 1993 provides that "Parties may agree to settle disputes arising in connection with technology transfer agreement by direct negotiation or in accordance with rules and procedures of conciliation and arbitration."

${ }^{56}$ For more on this, see Fekadu Petros, supra note 39.

${ }^{57}$ See also Aklilu Wolde Ammanuel (1973), 'The Fallacies of Family Arbitration under the 1960 Ethiopian Civil Code', 9 Journal of Ethiopian Law 176, 179 (wherein it is stated that reconciliation is part of family arbitration under Art. 676 of the Ethiopian Civil Code.

${ }^{58}$ Labour Proclamation No. 377/2003, Fed. Neg. Gaz., Year 10, No.12, 2004.

${ }^{59}$ Revised Family Code Proclamation No. 213/2000, Fed. Neg. Gaz., Extraordinary Issue, No. 1, 2000. 
seized with 'Petition for Divorce' by either of the spouses has to try to convince the parties to withdraw the petition. This should be achieved by reconciling the underlying differing interests held by the parties and seeking for a mutually agreeable solution. In other words, the court will use conciliation to settle the points of disagreements between the spouses. Thus, any court in which petition for divorce has been filed must, first of all, proceed to conduct the conciliation process between the spouses. This should be effected carefully thought-out conciliation steps including speaking to the spouses separately or jointly with a view of persuading them to renounce the petition for divorce and settling their disputes amicably.

Such a dispute settlement method, however, has its own inherent defects so much so that it has been critiqued as a non-viable method. Indeed, reposing conciliation proceeding and decision-making of a case in the same person(s) can prove itself a complete fiasco. Not only does it hinder the parties from making offers and admissions during the negotiation lest it should boomerang on them, but also lures them to be more focused in persuading the conciliator/decisionmaker instead of pursuing a concerted problem-solving approach. The parties may also find it difficult to confide in the conciliator/arbitrator for fear that their respective potential weaknesses in their cases may be exposed. Furthermore, the parties are tempted to closely scrutinize the words and proposals made during the proceedings by the conciliator/arbitrator in order to infer a likely result if arbitration becomes necessary.

Indeed, such a dispute settlement mechanism should not be imposed upon the disputing parties by law. Resort to such a mechanism by the parties should only be had if the parties are fully cognizant of the implications thereof and only with their express consent. Otherwise, it may be an unwelcome exercise for a conciliator-turned-arbitrator to piece up together evidence and other relevant information (such as confidential information, admissions or offers made for purposes of reconciliation only, documents presented by either party on 'without prejudice' basis, etc) during the negotiation processes and, thereupon, impose a decision. It can be safely said that such method is likely to be an antithesis to the entire modus operandi of the negotiation processes.

\section{b) Conciliation/Mediation}

Certain disputes are more conveniently settled in one forum than another. The policy choice must be mirrored by legislative enactments. In this regard, unless expressly prohibited by law or exclusively vested in the courts for litigation, all civil and commercial disputes can be legally and conveniently resolved through amicable dispute settlement mechanisms, depending upon the choice of the parties. For certain group of disputes, however, the need to entice or urge or even compel the parties to use a specific modality of dispute settlement is even more pressing for some clearly espoused policy rationale. 
In this regard, conciliation is made compulsory in resolving disputes related to cooperative societies which arise in connection to the 'organization, management, and operations' of a society or between societies. ${ }^{60}$ Secondly, in collective labor disputes, conciliation process is mandatory, at first instance, for the settlement of disputes arising out of or relating to disputes set out under Art. 142 of the Labour Proclamation No. 377/2003 in undertakings ${ }^{61}$ other than the essential public service undertakings. ${ }^{62}$

This position has been espoused by the Federal Supreme Court's Cassation Division in Construction Works and Coffee Technology Promotion Enterprise's Trade Union v. Construction Works and Coffee Technology Promotion Enterprise. ${ }^{63}$ The Cassation Division ruled that disputes in connection to 'wages and other benefits' envisaged under Art. 142(1)(a) of the Labour Proclamation No. 377/2003 in undertakings other than those essential public services undertakings should not be submitted for litigation to courts or LRB (ad hoc or permanent). The resolution of such disputes is vested exclusively in conciliators. The Cassation Division reasoned that any recourse to courts or the LRB, prior to or subsequent to conciliation, would deprive the employees or employers of their right to take industrial actions, i.e., strike or lock-out respectively. All other collective labour disputes set out under Art. 142(1)(b) through to (h) arising in all undertakings (irrespective of the kind of undertakings, i.e., employees in essential services or otherwise) are also amenable to conciliation pursuant to either Art. 141 cum Art. 158/2 (conciliation through the Ministry or at lower administrative echelons) or Art. 143 (through mutually agreed dispute settlement clauses).

Third, under the Revised Family Code, arbitration is compulsory for resolving disputes which arise out of or relating to the spouses' household managerial issues. ${ }^{64}$ Unlike the marital relationship under the 1960 Civil Code, which had accorded the husband the right to head the household, the new family codes (including those of the regional states) provide that both the husband and wife are jointly the heads of the family. In cases of absence of consensus in the decision-making processes, the impasse is overcome by an arbitral proceeding ${ }^{65}$ whose arbitral award may be appealed against by either spouse.

\footnotetext{
${ }^{60}$ Art.47-49 of the Federal Cooperative Societies' Proclamation No. 147/98, Fed. Neg. Gaz., Year 5, No.27, 1998.

${ }^{61}$ Art.141 of the Labour Proclamation No. 377/2003, supra note 58.

${ }^{62}$ Ibid. These 'essential public services undertakings' are enumerated under Art. 136(2) of the Labour Proclamation No. 377/2003.

${ }^{63}$ Cassation Case No. 49152 [2002EC], Fed. Sup. Ct. Rep., Vol.11, pp. 284-287.

${ }^{64}$ Art. 118 of the Revised Family Code, supra note 59.

${ }^{65}$ Ibid.
} 
Fourth, direct negotiation and arbitration are compulsory for resolving disputes arising from or in connection with petroleum concession contracts in Ethiopia. ${ }^{66}$ Fifth, direct negotiation and arbitration are compulsory for resolving disputes arising from mining concession contracts in Ethiopia. ${ }^{67}$ Finally, it is stipulated that attempt should, at first instance, be made by the complainants and the head of the procuring entity to amicably resolve bidders' and/or candidates' complaints relating to the decisions by procuring entities on the public procurement of public works contracts, public supply contracts, and services (including consultancy service contracts) and asset disposal procedures. ${ }^{68}$

It should also be noted that, in all the Standard Conditions of Contract (SCC) $)^{69}$ prescribed to all the federal procuring entities in 2011 by the Federal Public Procurement and Property Administration Agency (FPPPAA), it is provided that any disagreement, controversy or dispute between the procuring entity and the contractor/supplier/service-provider should be resolved through 'direct informal negotiation'. For instance, in construction contracts, every effort should be made by the consulting engineer and the contractor's contract manager to resolve the issues amicably; and if this fails, the parties have to appoint more senior representatives in order to resolve the dispute. It is only thereafter that either party can require that the dispute be referred to courts or arbitration. In this case, direct negotiation plays a significant role both in the tendering processes and contract performances of public procurement and disposal of assets.

${ }^{66}$ Art. 25 of the Petroleum Operations Proclamation No. 295/1986, Neg. Gaz., Year 45, No. 6, 1986. See also the 1994 Model Production Sharing Agreement for the Exploration and Production of Petroleum with the Government of Ethiopia, Art.16.2.

${ }^{67}$ Art. 76 of the Mining Operations Proclamation No. 678/2010, Fed. Neg. Gaz., Year 16, No.45, 2010.

${ }^{68}$ See Art.73 of the Ethiopian Federal Government procurement and Property Administration Proclamation No. 649/2009, Fed. Neg. Gaz., Year 15, No. 60, 9 September 2009. For detailed legal analyses of the complaints review and remedies system in the Ethiopian public procurement law, see Tecle Hagos Bahta (2012), 'Complaints Review and Remedies under the Federal Government Procurement Law in Ethiopia', 21 Public Procurement Law Review, No.5, pp.188-203.

${ }^{69}$ See http://ppa.gov.et/ (Last visited on 16 August 2019). See particularly Art. 26 of the Standard Conditions of Contract. 


\section{The Legal Framework for Conciliation}

\subsection{Rules of procedure and conduct}

Despite the flexibility and informal nature of amicable ADR methods, there are rules of procedure and conduct which direct the parties during the conciliation and mediation processes. Unlike negotiation, the conciliation processes are amenable to a few minimum procedural safeguards some of which should be imperatively observed and some others serve as the supplementary rules in assisting the disputing parties in reaching at a compromise. We shall, therefore, turn to shed light on the legal framework governing conciliation proceedings. ${ }^{70}$

\subsection{Conciliable (mediatable) disputes}

Parties are free to choose to either submit their disputes to amicable dispute settlement processes (i.e., negotiation or conciliation processes); or resort to arbitration or litigation. ${ }^{71}$ According to Cappelletti and Garth, most disputes, in fact, are settled informally without any recourse to lawyers, courts or other "third party" institutions. Cappelletti and Garth further noted that, 'disputes that typically are brought to lawyers are often settled prior to litigation, and those brought to courts are settled prior to the court's judgment'. ${ }^{72}$ Moreover, conciliated settlements of claims are particularly essential in interpersonal disputes such as between neighbors, family members, co-workers or trading partners - that is to say, between persons who find themselves in a lasting relation of "co-existence". 73

On the contrary, disputes arising from or relating to certain subject matters are for some justifiable public policy rationale proscribed from being submitted to the private dispute settlement mechanisms including conciliation. The common understanding is that disputes arising out of rights that cannot be disposed of (i.e., diritti indisponibili) are not conciliable. In this regard, disputes the adjudication of which is exclusively vested in courts; namely, issues such as the existence and validity of betrothal, marriage, divorce, and adoption are left for the sole jurisdiction of courts. Similarly, issues on nationality, filiation, capacity and status of a person, and criminal matters relate to public interest which cannot be left to the discretion of parties. The vesting of disputes arising

\footnotetext{
${ }^{70}$ See Arts. 3318-3323 of the Civil Code.

${ }^{71}$ This scenario is summed up in the precept that: "The law ... favors the compromise and settlement of disputed claims and will sustain such settlements if fairly made, because it is to the interests of the state that there should be an end to litigation." as cited by Mauro Cappelletti and Bryan Garth, Civil Procedure, in Mauro Cappelletti (ed.) International Encyclopedia of Comparative Law, Vol. XVI, p. 21.

${ }^{72}$ Id., at 69.

${ }^{73}$ See also Ibid.
} 
out of administrative contracts solely in courts has also used a similar rationale. $^{74}$

\subsection{Duty of the disputing parties}

For an amicable ADR to come to fruition, the role of the negotiating parties cannot be over-emphasized. At least, the parties are expected to cooperate in appointing a conciliator; showing willingness to share information with the conciliator; participating in good faith; remaining focused throughout and be part of the solution; refunding any reasonable expenses incurred by the conciliator; and, paying the remuneration to the conciliator, if agreed. ${ }^{75}$

\subsection{Duty of the conciliator}

During the negotiation processes, the conciliator should make sure that he/she should enable the parties to state their views. As discussed earlier, the conciliator may also propose a settlement agreement, if circumstances permit. Depending on the success or failure of the conciliation process, the conciliator should draw up the terms of the 'Compromise' or the 'Memorandum of NonConciliation' respectively. It is to be noted that the parties cannot bring the case to court until the Memorandum of Non-Conciliation is handed down by the conciliator. ${ }^{76}$ In practice, this is seldom complied with. The conciliator should also discharge his duties within six months ${ }^{77}$ as of the date of appointment unless otherwise agreed ${ }^{78}$ or provided by specific law. ${ }^{79}$

\subsection{Enforcement of conciliation clauses}

In order to fully amplify the legal position of conciliation clauses incorporated in contracts and statutes, it is important that we highlight how arbitral clauses inserted in the same documents are treated. An arbitral clause inserted in a contract cannot be unilaterally varied by a party. Until and unless the contracting parties choose to let it lapse by mutual agreement, ${ }^{80}$ both parties are duty bound to submit the issues in dispute to arbitration. Hence, in the presence of a valid arbitral clause, a recalcitrant party who ventures to refuse to participate altogether in the arbitration proceeding or part thereof risks an ex parte arbitral proceeding and eventually a default award. Does this position

\footnotetext{
${ }^{74}$ See Art. 315(2) of the Civil Procedure Code.

${ }^{75}$ Arts. 3318-3324 of the Civil Code.

${ }^{76}$ Art. 3320(2) cum Art. 3321(3) of the Civil Code.

${ }^{77}$ Art. 3321(1) of the Civil Code.

${ }^{78}$ Ibid.

${ }^{79}$ For instance, in resolving collective labour disputes, the conciliator is expected to discharge his/her duty within 30 days. See Art. 142(3) of Labour Proclamation No.377/2003, supra note 58.

${ }^{80}$ Art. 3344(1) of the Civil Code.
} 
equally apply to amicable ADR clauses (negotiation and/ or conciliation clauses) inserted in a contract?

We can envisage two possible approaches. To begin with, for a negotiation or conciliation process to succeed, it entirely depends on the free will and cooperative spirit of the parties. If either of the disputing parties is tempted to slow down or utterly stonewall it, then there is no next move. The question therefore is: whether specific performance could be sought for contractual conciliation or negotiation clauses. What would be the remedy if such dispute settlement mechanisms are compulsorily prescribed by legislative provisions ${ }^{81}$ in spite of which one of the parties refuses to participate?

Fekadu Petros argues that court-annexed ADR processes are imposed upon the parties and that 'ADR's legitimacy is eroded by its association with compulsion. It does not look or feel 'safe' to those forced to use it'. ${ }^{82}$ True, coercing or cajoling parties, short of their consensual commitment, -to be dragged into a process which cannot flinch by an inch save with the parties' full co-operation and interaction- is, of course, the very antithesis of amicable dispute settlement processes. Court-annexed conciliation processes had been in practice for some years in some of the federal courts. Notwithstanding the lures thereof, the legal bases, for so compelling the parties by the courts -to conciliate their disputes- seem to be missing.

It is, however, different when the conciliation clause emanates either from the considered policy rationale of the legislature or has been mutually agreed upon by the parties that when and if disputes arise, they should settle it amicably via conciliation processes. In the former case, courts realize that when laws are clear in terms, they are there to be executed. Thus, if the laws prescribe that direct negotiation or conciliation, or arbitration for that matter, is the convenient forum for resolving particularly designated types of disputes, deference should be granted to the will of the legislature regardless of the judge's own conviction. In such a case, the courts will only exercise the jurisdiction over the matter covered under the conciliation clause if the mediator or conciliator fails to bring the process into fruition ${ }^{83}$ or that the time-frame (set forth contractually or legally) within which he/she should have brought the process into fruition has expired. ${ }^{84}$

${ }^{81}$ See Fekadu Petros, supra note 39, p.119 (wherein it is stated that 'legally imposed ADR does not exist in Ethiopia'). The present writer has a different view for the reasons discussed above in Section 2 of this Article.

${ }^{82}$ Id., pp.119-120.

${ }^{83}$ This is the case scenario where the mediator or conciliator draws a memo of nonconciliation as envisaged under Art. 3320(2) of the Civil Code.

${ }^{84}$ Art. 3321 of the Civil Code. 
This line of argument is supported by the Cassation Division in its holding, in Dawit Abebe v Andnet No. 4 Condominium Housing PLC and Kamil Jemal, ${ }^{85}$ that multi-tiered dispute resolution clauses embodied either in legislation or contractual clauses must be complied with. The Cassation Division noted that in resolving disputes in cooperative societies, each step must be complied with prior to taking the dispute to the higher echelon in the dispute settlement mechanism; hence, instructing the parties to apply conciliation at first instance, and then arbitration prior to eventually seeking for judicial intervention. This position has been further reinforced by the Cassation Division in National Insurance Corporation of Ethiopia (NICE) v Commission for Sustainable Agricultural Rehabilitation ${ }^{86}$ wherein the Court stated that 'dispute resolution clauses should be enforced by courts'. Moreover, the fact that conciliation clauses, like any contractual stipulations, are laws between the parties and should be observed by the parties has been advanced by the ruling of the Cassation Division of the Federal Supreme Court in Boro Travil Construction Works PLC v Ephrem Shibru. ${ }^{87}$

When the parties, at the time of contractual negotiations, believe that disputes that arise out of or relating to their specific legal relationship can best be resolved amicably through negotiation or conciliation, there is no doubt in their minds that the contractual terms will guide conducts in their contractual relationship including when disputes surface in the said relationship. It might have even been the center-piece during their pre-contractual negotiations for which either of the parties might have made some concessions in favor of winning the conciliation clause for the obvious advantages it serves in the commercial dispute settlement processes. Conciliation processes might have been considered as critical for purposes of maintaining confidentiality, for instance, during pre-contractual negotiations in technology transfer agreements (which combine know-how, trade-secret, franchising agreements, etc), or government procurement of hard-defense materials and other businesses such as banking and insurance contracts. In such cases, leaving the enforcement of the conciliation clause to the unfettered discretion of either party would seriously diminish security of transactions for those who act relying on the legal system.

Thus, if the enforcement of the conciliation clauses in the aforementioned transactions is deemed proper, it should not make any difference -whatever the transaction may happen to be- because the parties had it negotiated and considered it wise to include the conciliation clause in their contractual relationships. Quite often, such conciliation clauses are inserted in the contract

\footnotetext{
${ }^{85}$ Cassation Case No. 91745 [2006 EC], Fed. Sup. Ct. Rep., Vol. 16, p. 38.

${ }^{86}$ Cassation Case No. 27349 [2000EC], Fed. Sup. Ct. Rep., Vol.7, p. 146.

${ }^{87}$ Cassation Case No. 106286 [2007EC], Fed. Sup. Ct. Rep., Vol.17, p. 358.
} 
in 'escalation clauses' or the so-called multi-tiered dispute resolution clauses. The use thereof is intended to be a condition precedent to the commencement of litigation or arbitration. ${ }^{88}$ If that is so, there is no reason why the specific performance of the conciliation clause cannot be demanded. At any rate, a validly agreed contractual term is a law between the parties ${ }^{89}$ and eventually it is worthy of the attention of the law enforcement bodies.

However, the parties cannot and should not be forced to reach a compromise agreement. Rather what is demanded of the parties here is the 'duty to participate in good faith' in the conciliation proceedings. It is well noted that '... what is enforced is not co-operation or consent, but participation in a process from which co-operation and consent might come'. ${ }^{90}$ To be more specific, it is emphatically stated that there is: 'utility in requiring parties, who are clearly bent on being difficult, to submit to conciliation processes ... Initial reluctance is not necessarily fatal to a successful mediation. If the parties enter into it as they all said they would, the skill of the mediator or conciliator would be given full play to bring about consensus. ${ }^{91}$ After all, it is the conciliator who is equipped with the necessary tactics and techniques for scanning the parties' differing positions in order to diagnose the underlying interests so that it may be possible to forge a remedial solution that works out for the optimal mutual gain.

\subsection{Confidentiality and immunity of conciliators from being witnesses}

During the conciliation proceedings, conciliators become inundated with flurry of all kinds of information insofar as the parties remain frank, open, and transparent. For this reason, a person who acted as a conciliator cannot and should not act as an advocate of either of the parties in any subsequent adversarial proceeding should the conciliation processes fail to come to fruition. ${ }^{92}$ The question, however, is whether a conciliator can be called upon as a witness by either party should the conciliation processes fail. There is no doubt

${ }^{88}$ See also Karl Mackie et al., supra note 47, p.172. Where it is meant to be otherwise, however, it should be clearly stated. In this regard, the authors of FIDIC Rainbow Suite (1999) have clearly stated that '.. both parties shall attempt to settle the dispute amicably before the commencement of arbitration. However, unless both parties agree otherwise, arbitration may be commenced [...] even if no attempt at amicable settlement has been made'. Peter Booen (2000), The FIDIC Contracts Guide: Conditions of Contract for Construction, for Plant and Design-Build, and for EPC/ Turnkey Projects, $1^{\text {st }}$ ed., p.314.

${ }^{89}$ Art. 1731 of the Civil Code.

${ }^{90}$ See Karl Mackie et al, supra note 47, p.174.

${ }^{91}$ Ibid, p.182, citing the Australian Chief Justice Andrew Rogers.

${ }^{92}$ See Arts. 19(1) and 20(3) of the Federal Court Advocates' Code of Conduct Council of Ministers Regulation No.57/1999, Fed. Neg. Gaz, Year 6, No.1, Sept. 1999. Same treatment is also envisaged under art. 19 of the UNCITRAL Conciliation Rules (1980), <http://www.uncitral.org/uncitral/en/uncitral_texts/arbitration/1980Conciliation_rules.html> (Last visited on 16 August 2019). 
that the conciliator's role should be privileged in order to create a degree of trust between the parties and the conciliator. ${ }^{93}$ Ethiopian law lacks in the necessary protection for the parties in this regard.

Maintaining the confidentiality of a dispute between the parties means that both the existence of the dispute between the parties and what is discussed during the proceedings should not be disclosed in subsequent arbitral or litigation proceedings if the amicable conciliation process fails to attain its objectives. In other words, statements, admissions, offers, or evidence that may have been introduced or discovered during the process for the sole purpose of exploring and effectuating mutually agreed-upon solutions cannot and should not be used as evidence in subsequent litigations or arbitrations should the said amicable conciliation process fail.

Without such confidentiality principle, conciliation proceedings are futile exercises. Indeed, it is quintessential for the success thereof, to be transparent, open, and focused on addressing the underlying interests of both parties; the parties should not be sidetracked to fret over subsequent legal consequences of their conduct or statements during the negotiation processes. The question, therefore, is whether the Ethiopian legal system accords protection against the disclosure of matters of confidentiality in the conciliation proceedings lest unwary parties who in good faith strive for the success of these conciliation proceedings (these proceedings being socially, economically and politically desirable) should be trapped. It is unfortunate that the answer is emphatic 'no'. Thus, in practice, it has been left to the discretion of the court to either grant or deny a party leave to introduce evidence pieced up together during the conciliation proceedings.

The follow-up question is: whether the Ethiopian legal system permits parties to enter into an agreement to the effect that the negotiation processes or evidentiary documents introduced in the process remain confidential. Would the Ethiopian courts give deference to such reciprocal promises? The Ethiopian Arbitration and Conciliation Center (EACC) had designed a model confidentiality agreement for the conciliation processes which had to be administered under the EACC's Institutional Mediation Rules. Whilst it may be hoped that the courts should accord it some degree of deference to such reciprocal promises, there is no guarantee yet under the legal system.

${ }^{93}$ In this regard, the UNCITRAL Conciliation Rules (1980) stipulate, under Art.19, that the parties are duty-bound to provide the conciliator immunity from being called upon as a witness in subsequent arbitral or judicial proceedings. 
Short of supporting legal provisions, the parties are left to devise a confidentiality agreement. Under such agreement, the parties vow to respect their reciprocal promises in the hope that the courts as well will enforce them. ${ }^{94}$ In the absence of guarantee for confidentially, the disputing parties participate in the conciliation processes fully conscious that each party should strategize its communications in a way that does not permit any inference of admissions, offers, or statements that may potentially be adduced in subsequent arbitral or litigation proceedings. The latter is, to say the least, inhibitive of communication flow.

And finally, from the conciliator's perspective, Article 3323 of the Civil Code is anachronistic which does not cater for the modern professional conciliator. The provision does not entitle the conciliator to remuneration; it only makes a provision (under Sub-Article 1) for a refund of 'any reasonable expenses he has incurred in the discharge of his duties'. Conciliators should, thus, be on guard to clearly and expressly make stipulations in their agreements on the amount of remuneration and modality of payment.

\section{Enforcing the Outcome (Compromise, Negotiated Settlement or Compromise Agreement) of ADR Methods}

It is noteworthy that if a negotiated settlement is reached as a result of direct negotiation, mediation or conciliation, then that agreement is easier to enforce than an arbitrator's award because it would have been concluded through the parties' own choice. ${ }^{95}$ Moreover, the disputing parties' consensual and amicably agreed-upon terms of settlement are solidified into a special contract, legally termed as 'compromise'. ${ }^{96}$ In a nutshell, an agreement reached between the disputing parties through the negotiation, mediation or conciliation processes will constitute 'negotiated settlement' or compromise'. ${ }^{97}$

94 Art. 24(1) of the Draft Evidence Rules of 5 April 1967 ( 27 Megabit 1959 E.C), provides: "In civil cases, no admission is relevant, if it is made either upon an express condition that evidence of it is not to be given, or under circumstances from which the court can infer that the parties agreed together that evidence of it should not be given".

Arguably this is the possible scenario (that is to say, the without prejudice clauses in a conciliation agreement or, in the absence thereof, the nature of conciliation proceedings per se respectively) that the draftsman must have had contemplated in the aforesaid Draft Rule.

${ }^{95}$ See also Nael Bunni, supra note 2, p.445.

${ }^{96}$ Art. 3307 of the Civil Code.

97 The English term 'compromise' as used in the Civil Code is equivalent to the term 'transaction' in French and 'transactio' in Latin languages. In other words, compromise is only used herein to refer to the French notion of transaction, not the French notion of compromis. The latter refers to an agreement to submit existing disputes to arbitration (i.e., submission agreement). Incidentally, it should also be mentioned that the term 
Due to inconsistent court practices in Ethiopia, ${ }^{98}$ the legal status of the outcomes of these amicable dispute settlement mechanisms has been marred by uncertainties. The problem has been compounded as 'compromise', as a legal concept, rarely attracted the attention of scholars ${ }^{99}$ in Ethiopia. Regardless of the relatively unregulated nature of negotiation and conciliation, the outcome thereof (that is to say, compromise) has received due legislative treatment in the Civil Code. ${ }^{100}$ In cases of conciliation, the negotiated settlement can only be binding upon the conciliating parties when the terms of the compromise are written and confirmed by it being signed by the parties. ${ }^{101}$

clause compromissoire refers to an agreement to submit future disputes to arbitration (i.e., arbitral clause). For more on this, see Sally Brown Richardson (2008-2009), 'Civil Law Compromise, Common Law Accord and Satisfaction: Can the Two Doctrines Coexist in Louisiana?', 69 La. L. Review, 175-217, 180-81 (wherein it is stated that, in civil law jurisdictions, such as France, Louisiana, and Quebec, 'transaction' is generally defined as a contract by which the parties, by making reciprocal concessions, terminate an existing dispute or prevent a future one.)

${ }^{98}$ The Appellate Division of the Federal Supreme Court, for instance, held the following in a well-known case:

'Furthermore, Art. 3312(1) of the Civil Code is a mandatory provision which stipulates that compromise, as between the contracting parties, has the effect of res judicata without appeal'. [Translation by author]. The Appellate Division erroneously relied on Art. 3312(2) of the Civil Code to disallow appeal against an arbitral award rendered following an arbitration agreement which contained 'finality clause'. For more on this, see Dragados $J$ \& P Avaz SA JV v Saba Construction PLC, EACC (Arbitral Awards) Rep., Vol. 3, p.82. See also Mukemil Mohammed v Miftah Kedir, supra note 1, p.182 (wherein the Court briefly addressed the difference between a compromise and an arbitration award).

99 A notable work on compromise is by Demissew Tessema (2000), Compromise as a Dispute Settlement Mechanism under the Ethiopian Civil Procedure Code, Senior Thesis, Addis Ababa University (Unpublished). It should be mentioned here that while credit should be given to the writer for the illuminating work on the subject, the said writer unduly considers the concept of 'compromise' as a dispute settlement mechanism rather than a product of a dispute settlement mechanism. See also Robert Allen Sedler (1968), Ethiopian Civil Procedure, HSI University, Addis Ababa, pp.186-190. For a comprehensive analysis on the distinction between ADR and Arbitration, see also Fekadu Petros (2009), supra note 39.

100 See Arts. 3307-3317 of the Civil Code of Ethiopia and Arts.274-276 of the Civil Procedure Code of Ethiopia.

${ }^{101}$ There is no such requirement for compromise contracts which are the outcome of the negotiation processes. The formality requirement for the compromise contract reached through negotiation is as enunciated under Art. 3308(2) of the Civil Code. In this regard, it is worthwhile to note that Art. 3308(2) is firstly predicated on the assumption that rights should be classified into non-disposable rights (i.e., diritti indisponibili) and disposable rights. The latter can further be categorized into those rights disposable only 
This written and signed document is a contract document ${ }^{102}$ wherein the parties' mutual interests and gains are embedded. Needless to say, it also contains the contractual rights and duties which were bargained for and upon which agreement has been reached either through direct negotiation processes or the third-party-neutral-led conciliation processes. For a compromise reached through direct negotiations, the format required for constituting a valid compromise, as enunciated under Art. 3308 of the Civil Code, is the format required by law for creating, modifying, and/ or extinguishing legal obligations [or rights] without consideration.

A multitude of legal rights and obligations are created, modified or become extinct 'without consideration' (ex titulo lucrativo) orally short of it being necessary to follow a certain format. It is, thus, legally possible for negotiating parties to have a valid compromise orally. However, it is hoped that prudent parties would think twice lest they should be ensnared in another round of disputes for the avoidance of which the parties would have had already spent time, cost and energy. In other words, post-settlement relationships between the parties may turn to be marred by uncertainties owing to the parties' failure to fully and precisely capture what was agreed upon. Equally true is the fact that oral agreements are difficult for purposes of enforcement by a court of law should a party remain recalcitrant to perform his/her part of the bargain under the compromise agreement. This is particularly true where compromise agreements are reached prior to the commencement of a court proceeding or for disputes in respect of which no suit has been instituted.

However, if the compromise is reached at the hearing, it should be 'reduced to writing and signed by the parties'. ${ }^{103}$ For compromises which are concluded subsequent to the commencement of a court proceeding, i.e., at the hearing or out of court, it is evident that Arts. 276-277 of the Civil Procedure Code shall apply. Art. 277 stipulates that a compromise agreement should be reduced to writing and signed by the parties. The foregoing position of the law should, however, mean to apply only for compromises reached through direct negotiations. It should be noted that terms of a compromise agreement reached through mediation or conciliation cannot be binding upon the parties unless, pursuant to Art. 3322(2) of Civil Code, the parties have 'expressly undertaken in writing to confirm them'. ${ }^{104}$

for consideration (disposition ex titulo oneroso) and those that are freely disposable (disposition ex titulo lucrativo).

102 Art. 3307 of the Civil Code.

${ }^{103}$ Art. 277(1) of the Civil Procedure Code.

${ }^{104}$ Art. 3322(2) of Civil Code states: 'The parties shall not be bound by the terms of the compromise drawn up by the conciliator unless they have expressly undertaken in writing to confirm them'. 
Art. 3307 of the Civil Code defines 'compromise' as "a contract whereby the parties, through mutual concessions, terminate an existing dispute or prevent a dispute arising in the future." Art. 274(1) of the Civil Procedure Code also offers for the functional definition of a compromise. It states that " $[\mathrm{t}]$ he parties may by a compromise agreement relating to all or some of the matters in issue terminate a dispute with respect to which a suit has been instituted."

From the reading of these provisions, the requirements for a valid compromise in Ethiopia are: ${ }^{105}$ (i) the existence or the possibility of a dispute between two or more parties, (ii) intention of ending (terminating) existing disputes or preventing future disputes, (iii) mutual or reciprocal concessions made by the disputing parties, and (iv) a contract between the parties. Nonetheless, this contract is not like an ordinary contract in that it is statutorily bestowed with the force of res judicata without appeal. ${ }^{106}$ To this effect, either party may invoke the preliminary objection as enunciated under Art. 244(2)(b) cum 244(2)(g) of the Civil Procedure Code to deny the other party of the relitigation of the issues that have been definitively dealt with under the negotiation or conciliation processes. This procedural right should be coupled with Art. 3312(1) of the Civil Code. ${ }^{107}$

In this regard, the Cassation Division of the Federal Supreme Court has made it clear, in Birru Qorcho $v$ Kifle Habdeta. ${ }^{108}$ that compromise once reached consensually by the parties is bestowed with finality. Similarly, the Cassation Division invoked Art. 3312 of the Civil Code and the issue of res judicata, and decided on finality of compromises in Kedir Haji Hussen and Others $v$ Amin Osman and Others. ${ }^{109}$ The Cassation Division thus reiterated its position on the fact that compromise agreements are not amenable to appeal and that such

${ }^{105}$ For more on these requirements, see Sally Brown Richardson, supra note 97, 175-217, 180-81.

${ }^{106}$ Art. 3312 of the Civil Code.

${ }^{107}$ Art. 3312(1) of the Civil Code states that ' $[a]$ s between the parties, the compromise shall have the force of res judicata without appeal'. The res judicata effect of compromise has also been established in the common law countries through case laws. In England, for instance, Lord Romilly M.R stated in Plumley v Horrell (1869) 20 L.T 473, that:

"Prima facie everybody would suppose that a compromise means that the question is not to be tried over again. That is the first meaning of compromise. When I compromise a law suit with my adversary, I mean that the question is not to be tried over again". Similarly, Bowen L.J in Knowles v Roberts (1888) 38 Ch. D 263 at 273, also noted thus: "As soon as you have ended a dispute by a compromise you have disposed of it." See David Foskett (1996), The Law and Practice of Compromise, $4^{\text {th }}$ ed., Sweet \& Maxwell, p.90.

${ }_{108}$ Cassation Case No. 25912 [2000EC] Fed. Sup. Ct. Rep., vol.5, p.343.

${ }^{109}$ Cassation Case No. 52752 [2002EC] Fed. Sup. Ct. Rep., vol.9, p.355. 
agreements render res judicata of all issues in relation to the disputes covered thereunder.

However, in Ananaytu Issa v Asina Hussen, ${ }^{110}$ the Cassation Division held that a compromise reached by disputing parties with intent to vary a court's judgment should be registered in the court. It is submitted that this holding is erroneous as it imposes extra burden upon the parties which is not envisaged in the law. The peculiar facts obtained in the foregoing case, which necessitated guarding the post-judgment settlement against deceitful practices by registering it in the court, might have informed the decision of the Court. Nevertheless, this will undoubtedly give rise to far-reaching negative repercussions to the sanctity of compromise settlements.

A compromise Agreement which is the outcome of a conciliation process that is initiated and reached, be it prior or post commencement of a court proceeding, is accorded with the legal recognition that courts at any level are duty-bound to respect and enforce. Parties would more often than not be forthcoming to discharge their side of the bargain. This is because in a truly consensual conciliation process, the parties fully control the outcome of the process, i.e., the compromise. In case one of the parties refuses to execute the compromise agreement, however, the court will not entertain any claim or action in relation to the issues upon which the compromise is reached. Nor is a party entitled to institute an appeal against the compromise agreement. This is because of its res judicata effect without appeal.

Thus, subsequent to the signing of a compromise agreement by the parties, courts would only intervene to enforce the operative parts of the compromise agreement against the breaching party. Nonetheless, in order for a compromise to enjoy the legal status accorded thereto under the Ethiopian legal system, the courts should be able to exercise minimum judicial oversight to see to it that it is not tainted with irregularities that render it void or invalid in the eyes of the law.

Given that compromise is a contract, the general requirements set out for the validity of contracts under the general principles of contract in the Civil Code apply mutatis mutandis. ${ }^{111}$ Moreover, compromise should (as a special contract) meet specific criteria which determine the validity of a compromise. Thus, a party to a compromise may wish to challenge the validity of a compromise on the following grounds: $:^{12}$

- that the negotiations (be it through direct negotiation or conciliation) took place on the basis of void or falsified document unless the parties, at the time

\footnotetext{
${ }^{110}$ Cassation Case No. 98263 [2007EC] Fed. Sup. Ct. Rep., vol.17, p.336.

${ }^{111}$ Arts.1675-2026 of Civil Code.

${ }^{112}$ See Arts. 3313-3316 of the Civil Code.
} 
of the contract, had in view the possibility that the document might be void or false; ${ }^{113}$

- there existed a judgment having the force of res judicata without appeal which had already settled all the issues contained in the compromise and which either or both were not aware of; ${ }^{114}$

- there was willful withholding of a document by either party; ${ }^{115}$

- the 'compromise' settles issues arising out of a contract whose objects (obligations) or causes $^{116}$ (purposes in view to the extent denoted in the document) are contrary to the law or to public morality, and, the terms of the compromise are contrary to the law or morals. ${ }^{117}$

It should be noted that compromise is chargeable with stamp duty. In the case of failure to do so, the compromise cannot be admitted in evidence; nor would it be noted upon or authenticated by any person or public office. ${ }^{118}$

\section{Conclusion}

A lot remains to be desired in the use of modern amicable dispute settlement processes in the commercial dispute settlement in Ethiopia. Whenever parties are willing to resort to such processes, it is not infrequent for the courts to fail them in the proper application and interpretation thereof. It has always been the desire of legislatures to draw the attention of the disputing parties towards the possibility of using these processes in the settlement of various disputes. This can be learnt from the Civil Codal provisions which point out to the parties of the need to resort to these processes in a bid to resolving their disputes amicably.

${ }^{113}$ Id., Art. 3313.

${ }^{114}$ Id., Art. 3314.

${ }^{115}$ Id, Art. 3315(2).

${ }^{116}$ Id., Art. 3316 cum Arts.1716-1718; note that unlike the simplified form of the doctrine of causa (referred to as 'motive' in the Civil Code) in private law contracting, special contracts -administrative contracts or public law contracting- conceive the original twopronged effect that it possesses under the French legal system: illicit cause and absence of cause. See Arts. 3170-71 of the Civil Code. For more on cause (causa), see Tecle Hagos Bahta (2017), 'Conflicting Legal Regimes Vying for Application: The Old Administrative Contracts Law or the Modern Public Procurement Law for Ethiopia?', 4 APPLJ 1, available at http://applj.journals.ac.za [visited on 16 August 2019].

117 Art. 277(1) of the Civil Procedure Code.

${ }^{118}$ A cumulative reading of Art. 2(1), Art. 6(8), Art. 10 and Section 3 of the Schedule of the Proclamation to Provide for the Payment of Stamp Duty No.110/1998. The amount payable for which both the conciliating parties assume the joint and several liabilities is $1 \%$ ad valorum for determinable amount and Birr 35 for undeterminable amount. 
The Civil Code embodies relatively modern rules on 'compromise' which, if properly understood and applied, can be the bloodline for the proper enforcement of settlement agreements reached through amicable dispute settlement processes. This does not, however, mean that the ADR methods are adequately regulated. On the contrary, these processes lack in the basic legal infrastructure for the proper implementation thereof. Matters of confidentiality, enforcement of ADR clauses, conciliator's immunity, etc... are the uncharted territories in the Ethiopian legal system.

It is envisaged that parties to an ad hoc conciliation process would resort to the UNCITRAL Conciliation Rules of $1980^{119}$ in conjunction or in lieu of the directory or permissive conciliation rules of the Civil Code and Civil Procedure Code (Arts. 274-77) subject, of course, to the imperative rules thereof. Needless to say, institutional conciliation proceedings would be guided by the respective institution's conciliation rules. ${ }^{120}$ Any party (federal or state) with the mandate of initiation of conciliation law(s) in Ethiopia should also no doubt consider the provisions on the UNCITRAL Model Law on International Commercial Conciliation (2002). ${ }^{121}$ It is, therefore, high time that issues of paramount importance in amicable ADR mechanisms are addressed through legislative interventions.

119 The UNCITRAL Conciliation Rules (1980) are adopted by the United Nations Commission on International Trade Law (UNCITRAL) on 23 July 1980 and approved by a resolution of the United Nations General Assembly of 4 December 1980 being '[c]onvinced that the establishment of conciliation rules that are acceptable with different legal, social and economic systems would significantly contribute to the development of harmonious international economic relations...'.

${ }^{120}$ See, for instance, the Conciliation/Mediation Rules of 2007 of the Arbitration Institute (AI) of the Addis Ababa Chamber of Commerce and Sectoral Association (AACCSA) at <http://www.addischamber.com/file/ARBITRATION/20131126/MediationAndConcilati onRule\%20\%28Engllish\%20Version\%29.pdf> (Last visited on 16 August 2019). See also the Rules of Arbitration and Mediation of 2005 of the now defunct Ethiopian Arbitration and Conciliation Center (EACC). (On file with the author).

${ }^{121}$ Supra note 92 (Last visited on 16 August 2019). 